\title{
Plans for Reconstruction of America's First
}

\section{Iron Works}

In the first volume of this BuLLETIN there appeared an article describing a collection, just presented to the Society, of documents relating to the Lynn Iron Works. ${ }^{1}$ After showing the importance of these documents for the history of what was the first successful iron works in this country, the account concludes: "At present, all that remains of the original Iron Works is a series of grass-grown hillocks marking the mounds of scoria from the plant, and these old documents, with their archaic expression and penmanship and worn paper, are now in the possession of The Business Historical Society." Since these words were written, the "grass-grown hillocks" have been disturbed and much of interest uncovered; many persons, singly and in groups, have contributed time, effort, and money to the ambitious project. It is the purpose of this note to bring the reader up to date on this development.

For those who have not visited the site of the Lynn Iron Works in Saugus (then a part of Lynn), a brief description may be helpful. The Saugus River flows sluggishly at the foot of what is now a rather steep bank but must then have been a gentle slope. It was in the upper reaches of this river that the bog iron, which led to the establishment of the Iron Works, was found. And the river itself furnished transportation and the power for operating the large bellows of leather. At the top of the slope is the ironmaster's house; a modern road (which accounts for the bank) separates it from the site of the Works. The Tudor structure, much enlarged and surrounded by pleasant lawns, is now the home of the First Iron Works Association. Not far away is the Scotch-Boardman House, where the prisoners taken in the battle of Dunbar and brought here to work in the mines were housed. It has for some time been the property of the Society for the Preservation of New England Antiquities. The existence of these two buildings in their historic setting is a continual inspiration to those who have in mind a larger restoration.

1 "The First Iron Works in the Colonies," BULletin of The Business HistoriCal Society, vol. i, no. 8 (July, 1927), pp. 7-12. 
Until recently the ironmaster's house and its grounds were in private hands; and though the last few owners appreciated the value of the ancient house, and in fact carried through its restoration, there were those who hoped that it might some day become public property. One of these, whose vision and perseverance were largely responsible for encompassing this end, was M. Louise Hawkes, a descendant of an early settler in Saugus. The first step came when the Daughters of the American Revolution were able to purchase the site of the Iron Works. Then, when Henry Ford wished to purchase and transport to Dearborn the oldest section of the ironmaster's house, Miss Hawkes, William Sumner Appleton, and others obtained aid from State and town to meet Mr. Ford's offer.

To administer the house, the First Iron Works Association was incorporated at the Harrison Gray Otis House in Boston, on October 11, 1943. The first president was Henry W. Porter, insurance man, who was also much interested in historical matters. Upon his death, in 1948, he was succeeded by J. Sanger Attwill, who is also president of the Lynn Historical Society. Miss Hawkes is clerk of the Association and curator of the Iron Works house.

Rapid strides have been made in furnishing the house in keeping with its period. Plans are under way for a museum in the barn, in the rear of which Edward Guy now makes copies of early American ironwork. Already numerous summer visitors have been attracted to the spot. In October, 1947, the Bay State Historical League held its fall meeting there. The Association has from the beginning attracted both those interested primarily in history and those interested in the manufacture of iron products. Men like Walter $\mathbf{R}$. Ingalls and Charles R. Hart, furnace authorities, Edward L. Bartholomew, engineer, and his son, Edward, Jr., metallurgist, and Quincy Bent, steelman, have investigated the beginnings of iron manufacture here and abroad. After determining where the Iron Works must have been, they were naturally anxious to see what foundations could be uncovered. Aid from the Iron and Steel Institute has made the work of excavation possible.

Work was begun last summer, under the direction of Roland Wells Robbins of Concord, who had investigated Thoreau's Walden site. Before cold weather necessitated a stop, the foundations of the blast furnace, of the stack, and of the bellows had been uncovered. Many artifacts, of iron, clay, and wood, were found; these have been temporarily displayed in the attic of the Association's house. When 
work is resumed in the spring, it is hoped that the site of the water wheel, its tail-race, the foundry, and the forges may be uncovered. Already much interest has been aroused. The January, 1948, issue of Steelways carried an illustrated article. News stories appeared in the Lynn Daily Evening Item on September 30, and December 10, 1948. Of the early discoveries, Edward G. Penniman wrote for the . $m$ : "First evidence that diggers had unearthed the site of the foundry came few days ago when they struck two charcoal beds, nearly four feet below the surface. Near-by was the stone base for what undoubtedly was a blast furnace. As they dug deeper, they came across beach sand, used in casting, and a bar of wrought iron nearly four feet long, caked unevenly by age."

The development of interest in the First Iron Works has also turned attention towards the documents. Some four items have been added to the collection of fifty-eight already in Baker Library. Two documents concerning a dispute between Henry Webb and Samuel Bennett were purchased from a New York dealer in 1943. They were copied from the Salem Court Records not long after the originals, which bear the dates 1657 and 1658, were introduced. Then there are two small items, received from Professor George L. Kittredge through Houghton Library. One represents the testimony of William Franklin, dated September 2, 1654; the other, an assignment of John Gifford to Henry Furber, September 14, 1652. Thus other documents, fugitives from the court records of the many suits in which the Iron Works and its workmen were involved, turn up from time to time. A publication of these is long overdue; possibly the present interest will result in its appearance.

Nathan M. Hawkes, addressing the Lynn Historical Society on February 7, 1902, said of the scoria: "The fleecy snows have mantled it, the sun has scorched it for two centuries, and only an occasional curious observer has disturbed its scanty covering of vegetation for some relic of the first manufacturing industry of the continent." If the plans of those concerned with the reconstruction are successful, there will rise beside the slag heaps the furnace and forges of an earlier day. The modern visitor will perhaps see how the colonists, from the materials available to them, forged iron for the implements of daily use. And one more of the beginnings of industry in this country will have been rescued from obscurity.

ROBERT W. LOVETT

Harvard University 